\title{
Mentoring in higher education
}

This article was published in the following Dove Press journal:

Advances in Medical Education and Practice

20 September 2016

Number of times this article has been viewed

\section{Shiria Banu \\ Fatema Zehra Juma \\ Tamkin Abas}

Manchester Medical School, The University of Manchester, Manchester, UK
Correspondence: Shiria Banu Manchester Medical School, The University of Manchester, Stopford Building, Oxford Road, Manchester, MI3 9PT, UK

Tel + 44 I6I 3060460

Email shiria.banu@student.manchester. ac.uk

\section{Dear editor}

We read the paper by $\mathrm{Al}$ Qahtani ${ }^{1}$ with great interest and agree that mentoring is an important educational tool. As medical students from the University of Manchester who have been exposed to various mentoring schemes, we have experienced some of the benefits mentioned in this article. We found that the mentoring schemes provided us with a valuable support system, enhanced our professional and social development, and opened doors for networking. We have primarily been involved in two different types of mentoring schemes and feel that each has its own benefits.

One was a tutor-led mentoring scheme where each student was assigned an academic tutor at the start of the program, with whom they had at least one formal meeting each semester. This was valuable as it provided all students with academic support and gave students the opportunity to raise any issues or concerns that they may not have otherwise addressed. This was made easier by having the same tutor throughout the program, ensuring a continuing and trusting relationship between the mentor and mentee. A significant advantage of this scheme was that all mentors were senior physicians and thereby helpful in providing advice and direction with regard to career development, good medical practice, student welfare, and professionalism.

The second was a student-led mentoring scheme where groups of 12 students were assigned four mentors (two males and two females). This was also introduced at the start of the program and was more informal; mentors could be approached as and when needed instead of having organized meetings. The mentors were all senior medical students with experience of the program, hence were able to relate to mentees, providing support and advice regarding social and personal issues. Additionally, having two mentors of each sex provided students with choice in regard to which mentor they approached. From personal experience, the student-led mentoring scheme was particularly useful in helping students to settle into the program, reducing anxiety, and encouraging students to raise any issues encountered.

Overall, we found both these schemes to be extremely useful and as discussed earlier, both have their own advantages. We believe that when developing a mentoring program, it is important to consider a combination of both schemes. Together, they not only provide

submit your manuscript | wawn dovepess con 
a strong mentoring network, but also allow addressing of the full range of issues that students may encounter.

\section{Disclosure}

The authors report no conflicts of interest in this communication.

\section{Reference}

1. Al Qahtani S. Students' knowledge of, and attitudes toward, mentoring: a case study at the Master's Program in Health and Hospital Administration. Adv Med Educ Pract. 2015;6:149-152. 


\section{Author response \\ Saad Al Qahtani \\ College of Medicine, King Saud bin Abdulaziz \\ University for Health Sciences, Riyadh, Saudi \\ Arabia}

Correspondence: Saad Al Qahtani

College of Medicine, King Saud Bin Abdulaziz University for Health

Sciences, PO Box 22490, Riyadh I 1426, Saudi Arabia

Email mcmasterer@hotmail.com

\section{Dear editor}

Thank you so much for giving me the opportunity to respond.

The authors in their letter to the editor stated a valid point. Their experience supported our finding about the benefits of mentoring. However, their observation came from different country and different level of education which I believe has to be validated by appropriate research.
The ease of mentorship is that it can be tailored as per the needs of the mentee, which also could become a disadvantage given the need for mentor at different levels of career, education, and their specific goals or needs. This means charting a certain guideline about mentoring is not easy, so is having a scale to measure it given all possibilities of bias.

The fact remains that at university level, the most important role the mentors can play is helping to deciding/choose the career path as per the strengths/weakness of the mentee. In addition, it is very important that the mentee knows the need for improvement which is best achieved by one-to-one mentoring.

\section{Disclosure}

The author reports no conflicts of interest in this communication.

Dove Medical Press encourages responsible, free and frank academic debate. The content of the Advances in Medical Education and Practice 'letters to the editor' section does not necessarily represent the views of Dove Medical Press, its officers, agents, employees, related entities or the Advances in Medical Education and Practice editors. While all reasonable steps have been taken to confirm the content of each letter, Dove Medical Press accepts no liability in respect of the content of any letter, nor is it responsible for the content and accuracy of any letter to the editor.

\section{Publish your work in this journal}

Advances in Medical Education and Practice is an international, peerreviewed, open access journal that aims to present and publish research on Medical Education covering medical, dental, nursing and allied health care professional education. The journal covers undergraduate education, postgraduate training and continuing medical education including emerging trends and innovative models linking education, research, and health care services. The manuscript management system is completely online and includes a very quick and fair peer-review system. Visit http://www.dovepress.com/testimonials.php to read real quotes from published authors.

Submit your manuscript here: http://www.dovepress.com/advances-in-medical-education-and-practice-journal 